\title{
Fen-Toplum Temelli Eğitsel Kısa Filmler Üzerine Bir Çalışma: Fen Bilgisi Öğretmenliği Örneği
}

\section{A Study on Science-Society Based Educational Short Films: Example of Science Education}

\author{
Fatma ÖNEN ÖZTÜRK*
}

Öz: Araştırmanın amacı öğretmen adayları tarafından hazırlanan eğitsel kısa filmlerin incelenmesi ve öğretim sürecinde kullanılmasına ilişkin görüşlerin belirlenmesidir. Araştırma tarama modelinde olup, 2014-2015 eğitim öğretim yılı bahar döneminde İstanbul'daki bir devlet üniversitesinin 2. sınıfinda okuyan 51 öğretmen adayıyla seçmeli bir ders olan "Fen Bilimleri ve Toplum" dersinde araştırmacı tarafindan gerçekleştirilmiştir. Araştırmaya katılan öğretmen adayları bu dersi alan grup içerisinden seçkisiz örnekleme yöntemiyle seçilmiştir. Araştırmada öğretmen adayları tarafindan fen ve toplum temelli 10 farklı film hazırlanmıştır. Araştırma verileri öğretmen adayları tarafından hazırlanan eğitsel kısa filmler ve araştırmacı tarafından hazırlanan açık uçlu soruyla toplanmıştır. Araştırma verileri dereceli puanlama anahtarı (rubrik) ve içerik analizi kullanılarak değerlendirilmiştir. Araştırmadan elde edilen bulgular filmlerde yer alan fen kavramlarının doğru bir şekilde kullanıldığını, fen-toplum ilişkisinin kurulabildiğini, filmlerin anlaşılır bir dile sahip olduğunu, sınıf seviyesine uygun olduğunu ve günlük hayatla ilişkilendirilebildiğini ortaya koymaktadır. Ayrıca öğretmen adayları filmleri meslekleri süresince etkili bir şekilde kullanabileceklerini düşünürken; filmlerin çoğunlukla dersin başında kullanılması gerektiğini düşünmektedirler. Öğretmen adayları filmlerin öğretim sürecini kolaylaştırma, ilgi çekmeyi ve günlük hayatla ilişki kurmayı sağlama, hayal gücünü geliştirme, kalıcılığı arttırma, farklı zekâ tiplerine firsat sunma, eğlenerek öğretme ve sorgulama becerisi kazandırma gibi olumlu niteliklerine atıfta bulunurken; yanlış öğrenmeye neden olabilme ve öğretmenin yerini alabilme gibi olumsuzluklara da atıfta bulunmuşlardır.

Anahtar kelimeler: Eğitsel kısa film, öğretmen adayı, fen eğitimi, fen bilimleri ve toplum

\begin{abstract}
The aim of the study is to analyze the educational short films prepared by teacher candidates and to assess the opinions regarding their use in the education process. The study is in the survey method and has been conducted with 51 teacher candidates studying their 2 nd year at a state university in Istanbul during 2014-1015 spring term. The study has been conducted within the "Sciences and Society" course which is operated as a selective course by the researcher. The teacher candidates participating in the study have been selected from the group taking this course with the method of random sampling. The study included 10 different educational short films prepared within the context of science and society. Educational short films and open-ended questions were used as data tools of the study. Data tools analyzed with a rubric and content analysis method. The results of the study revealed that scientific concepts were used correctly, the relation between science and society was effectively established, the films had a comprehensible language and were mostly suitable for the grade level. Besides these results teacher candidates consider that they can use films effectively during teaching process and also they consider using films at the beginning of the lesson. Teacher candidates explained the contributions of educational short films as "facilitation of the educational process, grabbing attention, establishing relations with the daily life, enlarging imagination, being permanent, offering opportunities for different types of intelligence, teaching in an enjoyable way and enabling the questioning skills". The teacher candidates also think that educational short films might have negative aspects such as "causing wrong learning and substituting the learning".

Keywords: Educational short film, teacher candidate, science education, science and education
\end{abstract}

\section{Giriş}

Günümüz teknolojilerindeki gelişmeler bilgiye ulaşma yollarının farklılaşmasına neden olmuştur. Özellikle internet erişiminin kolaylaşması ve farklı iletişim araçlarının bu süreçte 
kullanılması gibi pek çok etmen, bilginin elde edilme sürecinde de değişimi beraberinde getirmiştir. Bu durum elde edilen bilginin güvenilirliğine ilişkin pek çok sorunu beraberinde getirmiş olmasına rağmen, toplumun büyük bir kesimine bilgi aktarımında bulunması açısından önemli bir kaynak olarak da görülebilmektedir. Bireyler bilgiye ulaşmak için çoğunlukla görsel ve yazılı medya gibi, kolay ulaşılabilir kaynakları tercih etmektedirler. Bu araçlar yardımıyla farkl1 kavram ve konulara hem görsel sunum eşliğinde hem de anlaşılır bir dille ulaşılabilmekte böylece kompleks kavram ve konuların anlaşılması da kolaylaşmaktadır. Fenle ilgili kavram ve konular da soyut özellikler taşıyabilmekte, buna bağlı olarak da bireylerin fenle ilgili kavramalarında çeşitli sıkıntılar olabilmektedir.

Dünya'da ve ülkemizde yaşanan reform hareketlerine bağlı olarak fen eğitimine yönelik vurgu artmış ve gündelik hayatımızdaki fen oldukça önemli bir rol kazanmıştır. Fenin toplumsal yaşamın bir parçası olduğu ve farklı disiplinlerle ilişki içerisinde olduğu yadsınamaz bir gerçektir. Birey fen hakkındaki bilgisini anlamlandırabildiği, özümseyebildiği, gündelik hayatıyla birleştirebildiği ve yorumlayabildiği sürece fen daha anlaşılır bir hale gelmektedir. Nitekim bu durum üzerindeki farkındalığın artmasıyla birlikte fen okur-yazarlığı öğretim programları içerisinde odak bir noktada yer almaya başlamıştır. Fen bilimleri dersi öğretim programı bireysel farklılıkları ne olursa olsun tüm ögrencilerin fen okuryazarı olarak yetiştirilmesini hedeflemektedir (MEB, 2013). Bu durum öğrencilerin fenle ilgili kavramlara ve süreçlere yönelik farkındalığının da artmasına neden olmuştur.

\section{Filmler ve Fen Ĕ̈itimi}

Birey sahip olduğu bilgi birikimi ile gündelik yaşamındaki olayları ilişkilendirebildiği sürece, bilgiye yönelik farkındalığı artacak ve öğrendiği kavramları anlamlandırabilecektir. Pekdağ ve Le Marechal (2007b) da öğrenmenin yalnızca bilgi edinme ile gerçekleşmediğini, aynı zamanda bilginin yapılandırılması sürecinin de hatırlanması gerektiğini belirtmekte; bu bağlamda belli bir metne ve sözlü iletişime dayanan bir öğretimin anlamlı öğrenmeyi sağladığını belirtmektedirler. Özellikle fen gibi soyut kavramların ve formüllerin çok olduğu, öğrencilerin anlamakta zorlandığı bir alanda bu anlamlandırma sürecinin sağlanabilmesi için farklı kaynaklara ihtiyaç duyulabilmektedir. Bu kaynaklardan birisi de görsel ve yazılı medya araçlarıdır. İnsanlar günlük hayatlarının yaklaşık \%70'lik kısmını medya araçları ile geçirmektedirler. Medya araçları her yaştan bireyin hayatını etkileyebildiği gibi öğrencilerin de hayatlarını etkileyebilmektedir. Öğrenciler okul öncesi dönemden itibaren, medyanın hem alıcısı hem de üreticisi ve dağıtıcısı olabilmektedirler (Tüzel, 2013).

Film, televizyon, tepegöz, slayt, şekil, şema, basılı araçlar ve bilgisayarlar çeşitli medya araçları olmakla birlikte, bu araçlar eğitsel amaçlı mesajlar taşıdıkları zaman "eğitsel medya" olarak nitelenmekte ve günümüzde eğitimciler daha iyi öğrenmeyi ve akılda tutmayı sağlamak amaciyla kullanmaktadırlar (Barkan ve Eroğlu, 2004). Selanik Ay (2010) da hareketli resimler, televizyon, slayt, film şeridi, kayıtlar ve diğer eğitsel medyaların öğrenme sürecinde kullanımının önemli bir değeri olduğunu belirtmektedir.

Eğitim-öğretim sürecinde kullanılabilecek eğitsel medya araçlarından birisi de genel anlamda filmler özel anlamda eğitsel nitelikteki filmlerdir. Depover ve diğerlerinin (1998) belirttiğine göre bilgi ve iletişim teknolojilerinin bir parçası olan filmler, eğitim ortamları içerisinde 50 yıldan beri kullanılmaktadır (aktaran Pekdağ ve Le Marechal, 2007a). Öztaş (2008) da filmlerin her ne kadar kurmaca bir yap1 içerisinde kurulsa bile belli belgelere dayandığı sürece eğitimde mutlaka kullanılabilir olduklarını ifade etmiştir. Benzer bir şekilde Attia, Rahman ve Kamel (1997) görsellerin öğrenme stratejilerinin etkililiğini arttırdığını belirtmekte ve gerçek yaşama yakın konuları içerdiği sürece filmlerin tartışmaya olanak tanıdığını, bu bağlamda sınıf ortamında kullanılmasının da önemli bir etkisinin olduğunu belirtmektedir.

Pekdağ ve Le Marechal'ın (2007a) belirttiğine göre de psikolojik güdüleme sağlama, gözle görülmeyen olayların görselleştirilmesine neden olma ve kalıcılığı arttırma gibi pozitif etkileri nedenleriyle filmler eğitim ortamlarında kullanılmalıdır. Stoddard (2009) da filmlerin öğrenme ve öğretme süreci için etkili bir araç olduğunu belirtmekle birlikte, bilginin tarafsız bir 
kaynağı olduğunu da belirtmektedir. Literatürde yer alan farklı çalışmalar filmlerin öğretim sürecinde etkin olarak kullanılabilecek ögretim materyallerinden biri olduğunu göstermekle birlikte; eğitsel nitelik taşıdığı zaman daha da etkin olarak kullanılabileceğini gösterir niteliktedir. Pekdağ ve Le Marechal (2010) ile Goll ve Woods (1999) filmlerin kimya eğitiminde kullanılmasının oldukça etkili sonuçlar ortaya koyduğunu belirtmiştir.

Bruner (2008) eğitsel filmlerin, öğrencilere dolaylı deneyimler sunan ve öğrenmeöğretme sürecini zenginleştiren araçlar olduğunu belirtmiştir (aktaran Akbaş, Canoğlu ve Ceylan, 2015). Birkök'ün (2008) belirttiğine göre ise filmlerin öğretim sürecinde kullanılmas1 ile karmaşık bilgiler daha kolay anlaşılmakta, kurgulanmış olan bilginin tümü hem dinamik hem görsel hem de işitsel olarak aktarılmakta ve öğretimin yanı sıra davranış modelleri de öğrenciye aktarılabilmektedir. Bunun yanı sıra Demircioğlu (2007) üst düzey düşünme becerileri olan sentez, analiz ve değerlendirme becerilerinin de filmler aracilı̆̆ıla öğrencilere kazandırılabildiğini belirtmektedir. Akbaş ve diğerleri (2015) yapmış oldukları çalışmada öğretmen adayları tarafından hazırlanan filmlerin ve videoların; kendi öğrenme aktivitelerini planlama ve uygulama, kendi deneyimleri hakkında yansıtıcı düşünmeyi sağlama ve öğrenme sürecini anlamlandırma gibi birçok olumlu davranışı kazandıracağını belirtilmektedir.

Birkök (2008) filmlerinin bu denli etkin bir öğretim aracı olmasının nedeni sanat ve teknolojinin entegre bir şekilde çalışması, filmler aracılığıyla kapsamlı, karmaşık ve yoğun bilgilerin geniş kitlelere ulaştırılması, tutum ve davranış gibi bilgilerin aktarılabilmesi olarak açıklamaktadır. Filmlerin öğretim sürecinde kullanımına ilişkin olumlu pek çok sonuç bulunmasına karşın İnce Yakar (2013) filmlerin; film kullanımı kurallarına uyulmaması, filmlerin uzunluğunun ders süresiyle uymaması, üretim maliyetinin yüksek olması, sadece bir öğretim aracı olduğunun unutulması, olması gerektiğinden fazla kullanıldığında okuduğunu anlama becerisini olumsuz yönde etkilemesi gibi birtakım zararları ve sınırlılıklarının da ortaya çıkabileceğini ifade etmiştir. Cuban (1986) ise öğretmenlerin sınıf içerisindeki rolünü etkilemesi, ilgili dersin öğretim programına ara vermesi ve filmlerin eğlence aracı olarak görülmesi gibi nedenler dolayısıyla filmlerin öğretim sürecindeki kullanımının kısıtlandığını belirtmektedir (aktaran Akbaş, 2011). Filmlerin genel olarak olumlu etkilerinin olduğu görülmekle birlikte; filmlerin özellikle eğlence amaçlı olarak düşünülmesi, öğretim sürecinde kullanımına yönelik olumsuz bir durum ortaya koymaktadır. Oysaki McClusky (1947) eğitim ve eğlenmenin aynı amaçları taşımadığını fakat eğlendiren bir filmin aynı zamanda eğitsel nitelikler taşıyabileceğini de belirtmiştir.

Farklı çalışmalardan elde edilen sonuçlar filmlerin öğretim sürecinde kullanımına ilişkin pek çok olumlu durumu ortaya koymakla birlikte; olumsuz durumların da yer alabileceğini göstermektedir. İnce Yakar (2013) eğitim-öğretim amaçlı filmlerin daha yaygın ve etkili biçimde kullanılabilmesi için okullarda gerekli teknolojinin bulunması, müfredata uygun filmlerin temin edilmiş olması, gerektiğinde kullanılmak üzere arşivlenmiş ve korunmuş olması, öğretmen eğitiminin tamamlanmış olması ve bu konudaki araştırmaların sayısının artması gerektiğini belirtmektedir. Buna karşın Birkök (2008) henüz salt eğitim amaçlı belli bir bilimsel konuyu ele alan sinema filmlerinin yaygın olarak çekilmediğini, önümüzdeki dönemlerde eğitim modelleri ve stratejileri için filmlerin vazgeçilmez bir eğitim aracı olma yolunda ilerlediğini belirtmektedir. Barnett, Wagner, Gatling, Anderson, Houle ve Kafka (2006) da popüler kültürel filmlerin, öğrencilerin bilimsel kavramları anlamaları üzerindeki etkisini ölçen az sayıda çalışmanın yer aldığını ifade etmektedir. Pekdağ ve Le Marechal (2010) ise yapmış oldukları çalışmada öğretmenlerin sınıf ortamında izlemiş oldukları filmlerin önemini yeterince fark etmediklerini belirtmişlerdir.

Farklı araştırmalardan elde edilen sonuçlar filmlerin öğretim süreci içerisinde etkin olarak kullanılabilecek öğretim materyalleri olduğunu göstermekle birlikte, alan yazında yer alan çeşitli eksikliklere de dikkati çeker niteliktedir. Bu durum araştırmanın odak noktasını oluşturmuş, bu bağlamda araştırmada geleceğin öğretmenleri olacak olan öğretmen adaylarıyla çalışılmıştır. Genellikle fen dersleri öğrencilerin anlamakta zorlandıkları bir alan olmakla birlikte, özellikle günümüzdeki pek çok reform hareketi ile bu durumun aşılmas1 hedeflenmektedir. Nitekim son zamanlarda fen eğitiminin gündelik yaşamla bir araya 
getirilerek, hem fen kavram ve konularına yönelik anlama düzeyinin hem de ilginin arttırılması üzerine odaklanılmaktadır. Bu bağlamda araştırmada da bu amaçla öğrencilerin gündelik yaşamlarında pek çok kez etkileşime girdikleri medya araçlarından biri olan eğitsel kısa filmler ele alınmıştır. Ayrıca fen ve gündelik yaşamı bir araya getirebilmek bağlamında günlük hayatımızda yer alan problemlere odaklanılmış ve bu problemlerin çözümü üzerinde durulmuştur. Okumuş'un (2014) belirttiğine göre de kısa film çeşitliliği bakımından toplum sorunlarına daha çok eğilmek durumundadır. Araştırmada da bu durum göz önüne alınmış ve öğretmen adaylarının okumuş oldukları bölüm gereği fen kavram/konularından yola çıkmaları ve fen ile toplumu bir araya getirebilecekleri bir sorun bağlamında eğitsel nitelikli bir film hazırlamaları beklenmiştir. Araştırmadan elde edilen sonuçlar filmlerin öğretim sürecinde kullanılmasına ilişkin görüşleri ortaya koymakla birlikte; öğretmen adaylarının fen ve toplum bağlamında yer alan sorunları farklı bakış açılarına göre nasıll ele aldıkları ve yorumladıklarına ilişkin dönüt sağlayacağı da düşünülmektedir. Bu bağlamda araştırmanın amacı; öğretmen adaylarının hazırlamış oldukları eğitsel kısa filmlerin incelenmesi ve öğretim sürecinde kullanılmasına ilişkin görüşlerinin değerlendirilmesidir. $\mathrm{Bu}$ amaç doğrultusunda araştırma soruları şu şekilde belirlenmiştir.

1.Öğretmen adayları tarafından hazırlanan eğitsel kısa filmler, araştırmanın amacı doğrultusunda belirlenen nitelikler açısından nasıldır?

2.Öğretmen adayları tarafından hazırlanan eğitsel kısa filmlerin olumlu ve olumsuz özellikleri nelerdir?

3.Öğretmen adaylarının eğitsel kısa filmlere ve öğretim sürecinde kullanılmasına ilişkin görüşleri nelerdir?

\section{Yöntem}

\section{Arașturmanın Modeli ve Çalış̧ma Grubu}

Araştırmada öğretmen adaylarının hazırlamış oldukları eğitsel kısa filmlerin incelenmesi ve öğretim sürecinde kullanılmasına ilişkin görüşlerinin belirlenmesi hedeflendiği için, araştırma tarama modeline uygun niteliktedir. Araştırma 2014-2015 eğitim öğretim y1lı bahar döneminde gerçekleştirilmiş olup; araştırmaya İstanbul'da bulunan bir devlet üniversitesinin 2. sınıfinda okumakta olan 51 öğretmen adayı katılmıştır. Araştırmaya katılan öğretmen adayları 18-22 yaş aralığında olup, öğretmen adaylarından 33'ü kız, 18'i ise erkektir. Araştırma, araştırmacı tarafindan seçmeli bir ders olarak yürütülmekte olan, 2 kredi ve 2 teorik saatten oluşan "fen bilimleri ve toplum" dersinde gerçekleştirilmiştir. Araştırmaya katılan öğretmen adayları bu dersi alan grup içerisinden seçkisiz örnekleme yöntemi kullanılarak seçilmiştir.

\section{Ĕ̈itsel kısa filmlerin hazırlanması}

Veri toplama araçlarından biri olan eğitsel kısa filmler, öğretmen adayları tarafindan araştırmacının rehberliğinde hazırlanmıştır. Araştırmada fen ve toplum bağlamında hazırlanan 10 farklı eğitsel kısa film incelenmiştir. Eğitsel kısa filmler hazırlanmadan önce araştırmacı tarafindan öğretmen adaylarına 3 hafta süren bir eğitm verilmiştir. Bu eğitim sürecinde görsel ve yazılı medya araçları ile bu araçların eğitimde kullanılması gibi genel bilgiler sunulmuş; ardından öğretmen adaylarına görsel medya araçlarından biri olan eğitsel kısa filmin ne olduğu, öğretim sürecinde nasıl kullanılacağı, eğitsel kısa film ile kamu spotu arasındaki farklılıkların neler olduğu, eğitsel kısa filmlerin öğretim sürecindeki etkililiği gibi farklı konularda bilgilendirmede bulunulmuş; ayrıca farklı medya kaynaklarında yer alan eğitsel kısa film örnekleri de incelenmiştir. Ayrıca araştırmada öğretmen adayları eğitsel kısa filmleri hazırlamadan önce; filmlerin nasıl hazırlanacağ film çekim sürecinin nasıl yürütüleceği, senaryonun nasıl hazırlanacağı, filmlerin süresi, çekim sürecinde kullanılan 1şık-ses-mekan-ortam koşulları gibi farklı etmenlerin nasıl belirleneceği, filmlerin hangi programlar kullanılarak bilgisayara aktarılacağı gibi farklı konu başlıkları da araştırmacı tarafindan aktarılmıştır.

Eğitsel kısa filmler hazırlanırken öğretmen adaylarının 4-6 kişiden oluşan gruplarda çalışması sağlanmış ve gerekli görüldüğü durumlarda konuk oyuncunun yer alması ve sokak 
röportajı veya çeşitli medya araçları gibi farklı kaynakların kullanılması mümkün kılınmıştır. Filmlerin hazırlanması amacıyla öğretmen adaylarına 8 haftalık bir süre verilmiştir. Eğitsel kısa filmler hazırlanırken öğretmen adaylarından hazırlamış oldukları bu kısa filmleri ilköğretim müfredatında yer alan bir fen konusundan yola çıarak tasarlamaları ve bu süreçte de toplumsal bir soruna yer vermeleri beklenmiştir. Öğretmen adaylarının seçmiş oldukları fen konuları kendi istekleri doğrultusunda belirlenmiş olup bu konuda her hangi bir kısıtlama getirilmemiştir. Hazırlanan her bir kısa film $15 \mathrm{dk}$ süre ile sınırlandırılmıştır. Öğretmen adayları tarafından hazırlanan eğitsel kısa filmlere ilişkin ayrıntılara Tablo 1'de yer verilmiştir.

Tablo 1

Eğitsel Kısa Filmlere İlişkin Ayrıntılar

\begin{tabular}{|c|c|c|c|c|c|}
\hline & $\begin{array}{l}\text { Filmin } \\
\text { Ad1 }\end{array}$ & Süre & Ünite & Filmin İçeriği & Toplumsal Temel \\
\hline 1 & $\begin{array}{l}\text { Aynı } \\
\text { genden } \\
\text { gelenler }\end{array}$ & 9'23', & $\begin{array}{l}\text { 8. sınıf/Hücre } \\
\text { bölünmesi ve } \\
\text { kalıtım }\end{array}$ & $\begin{array}{l}\text { Ayrı ve tek yumurta ikizlerinin doğumuyla } \\
\text { başlayan film, ikizlerin birbirlerine } \\
\text { benzerlik ve farklılıkları ile çevresel } \\
\text { etmenlerin etkisi üzerine odaklanıyor. } \\
\text { Filmde mendel'in çalışmalarına atıfta } \\
\text { bulunan bir sahne ile birlikte ilgili fen } \\
\text { konusunun anlatımına odaklanılıyor. }\end{array}$ & $\begin{array}{l}\text {-Çocukların } \\
\text { ailelerinden farklı } \\
\text { olmalarının nedenleri } \\
\text {-Tek ve çift yumurta } \\
\text { ikizlerinde çevresel } \\
\text { faktörlerin etkisi }\end{array}$ \\
\hline 2 & Bitkiler & $12^{\prime} 42^{\prime \prime}$ & 6. sınıf/Bitkiler & $\begin{array}{l}\text { Filmde tayini çıkan bir öğretmenin } \\
\text { öğrencileri ile parkta yapmış olduğu son } \\
\text { ders canlandırılıyor. Bu ders sürecinde } \\
\text { öğretmen öğrencilerine, bitkiler } \\
\text { konusunda yanlış bilinen bazı kavramlara } \\
\text { ilişkin bilgilendirmede bulunuyor. }\end{array}$ & $\begin{array}{l}\text {-Bitkilerin canlılar için } \\
\text { önemi }\end{array}$ \\
\hline 3 & $\begin{array}{l}\text { Bu dünya } \\
\text { bizim }\end{array}$ & 9'54', & $\begin{array}{l}\text { 7. sınıf/İnsan } \\
\text { ve çevre }\end{array}$ & $\begin{array}{l}\text { Filmde sabah kalktığında karanlık bir güne } \\
\text { başlayan bir öğrencinin günü konu } \\
\text { ediliyor. Öğrenci gün içerisinde } \\
\text { öğretmeninden bu olayın nedenine ilişkin } \\
\text { bilgi ediniyor. Film yaşanan bu olayların } \\
\text { bir rüyadan ibaret olduğunu gösteren bir } \\
\text { sahne ile sonlanıyor. }\end{array}$ & $\begin{array}{l}\text {-Çevre sorunları } \\
\text {-İnsanların çevreye } \\
\text { yönelik duyarsızlığı }\end{array}$ \\
\hline 4 & - & 8’29’, & $\begin{array}{l}\text { 8.sinif } / \text { Basit } \\
\text { makineler }\end{array}$ & $\begin{array}{l}\text { Film birkaç arkadaşın birbirlerine yapmış } \\
\text { oldukları ziyaret sahnesi ile başlıyor. Bu } \\
\text { süreçte müzik ve canlandırma eşliğinde } \\
\text { evde kullanmış olduğumuz farklı basit } \\
\text { makinalara örnekler veriliyor. }\end{array}$ & $\begin{array}{l}\text {-Günlük hayatımızı } \\
\text { kolaylaştıran aletler }\end{array}$ \\
\hline 5 & - & 7'42', & $\begin{array}{l}\text { 7. sinif } \\
\text { /Elektriklenme }\end{array}$ & $\begin{array}{l}\text { Film bir annenin çocuğu ile evinde } \\
\text { geçirdiği bir günü anlatan sahne ile } \\
\text { başlıyor. Filmde elektriklenme olayının } \\
\text { anlatıldığ ç çşitli sahnelerle konu anlatımı } \\
\text { gerçekleştiriliyor. }\end{array}$ & $\begin{array}{l}\text {-Kazağımızı çıkarırken } \\
\text { çıkan seslerin nedeni }\end{array}$ \\
\hline 6 & $\begin{array}{l}\text { Bizim } \\
\text { evin } \\
\text { halleri }\end{array}$ & 7'54', & $\begin{array}{l}\text { 7. sinif } / 1 \text { s1 ve } \\
\text { sicaklik }\end{array}$ & $\begin{array}{l}\text { Film üniversiteyi yeni kazanmış bir } \\
\text { öğrencinin, ev arkadaşları ile birlikte yeni } \\
\text { bir eve yerleşmesini konu alıyor. } \\
\text { Öğrencinin ateşlenmesi ve bu süreçte } \\
\text { yapılması gerekenlere ilişkin çeşitli } \\
\text { tartışmalar ile ıs1 ve sıcaklık kavramlarına } \\
\text { değiniliyor. }\end{array}$ & $\begin{array}{l}\text {-Toplumsal alanlarda } \\
\text { birlikte yaşam }\end{array}$ \\
\hline 7 & $\begin{array}{l}\text { Yild1z } \\
\text { planı }\end{array}$ & $20^{\prime} 12^{\prime \prime}$ & $\begin{array}{l}\text { 7.sınıf/güneş } \\
\text { sistemi ve ötesi }\end{array}$ & $\begin{array}{l}\text { Film farklı özelliklere ve sosyal hayatlara } \\
\text { sahip } 4 \text { bilim insanının araştırma } \\
\text { merkezindeki çalışmaları ile başlıyor. } \\
\text { Filmde kaza geçiren bir bilim insanının } \\
\text { bilgilerini unutması ve bu bilgilerin } \\
\text { hatırlatılması sürecinde konunun } \\
\text { özetlenmesini konu alıyor. }\end{array}$ & $\begin{array}{l}\text {-Astronom/astrolog } \\
\text { kavramlarına ilişkin } \\
\text { yanılg1 } \\
\text {-Uzay kirliliği }\end{array}$ \\
\hline 8 & $\begin{array}{l}\text { Fatma'nın } \\
\text { ilaç }\end{array}$ & 9’20', & $\begin{array}{l}\text { 7.sinif/duyu } \\
\text { organlar1 }\end{array}$ & $\begin{array}{l}\text { Film hasta olan ancak ilaç içmek } \\
\text { istemeyen bir çocuğun sahnelenmesiyle }\end{array}$ & $\begin{array}{l}\text {-İlaç içmeyi sevmeyen } \\
\text { çocuklar }\end{array}$ \\
\hline
\end{tabular}




\begin{tabular}{|c|c|c|c|c|c|}
\hline & maceras1 & & & $\begin{array}{l}\text { başliyor. Filmde en bilgisi öğretmeni olan } \\
\text { anne ilacı çocuğun burnunu kapatarak } \\
\text { içiriyor ve bunun nedenini yapmış olduğu } \\
\text { bir deneyle anlatıyor. }\end{array}$ & \\
\hline 9 & - & 9'10', & $\begin{array}{l}\text { 6.sinif/İnsan } \\
\text { vücuduna } \\
\text { yolculuk }\end{array}$ & $\begin{array}{l}\text { Film spor yapmaya gitmiş kişilerin } \\
\text { sahnelenmesi ile başliyor. Bu süreçte terli } \\
\text { terli soğuk su içen birinin yapmış olduğu } \\
\text { bu davranışın yanlış olduğu vurgulanarak; } \\
\text { bunun nedeni bir drama ile açıklanıyor. }\end{array}$ & $\begin{array}{l}\text {-Terliyken su içmenin } \\
\text { olumsuz etkileri }\end{array}$ \\
\hline 10 & - & 6’37', & $\begin{array}{l}\text { 6.sinif/kuvvet } \\
\text { ve hareket }\end{array}$ & $\begin{array}{l}\text { Film pikniğe giden birkaç arkadaşın oyun } \\
\text { oynama sahnesi ile başliyor. Oyun } \\
\text { oynarken kuvvet ve hareket ile ilgili } \\
\text { karşlaşılan farklı durumların, müzik } \\
\text { eşliğinde sahnelenmesi ile ilgili } \\
\text { kavramlara odaklanılıyor. }\end{array}$ & $\begin{array}{l}\text {-Günlük hayatta, } \\
\text { kuvvet ve harekete } \\
\text { ilişkin anlaşılması güç } \\
\text { konular }\end{array}$ \\
\hline
\end{tabular}

Tablo 1'de de görüldüğü gibi öğretmen adaylarının hazırlamıș oldukları eğitsel kısa filmler genellikle 6. ve 7. sınıf seviyesinde olmakla birlikte; ortalama $10 \mathrm{dk}$ sürmektedir. Ayrıca öğretmen adaylarının seçmiş oldukları konuların genellikle günlük yaşamdaki problemlerden yola çıkılarak tasarlandığı da görülmektedir. Öğretmen adaylarının hazırlamış oldukları filmler belirlenen tarihlerde sınıf ortamında sunulmuş ve filmlerde yer alan fen konu/kavramları ve ele alınan toplumsal sorun ayrıntılı bir şekilde irdelenmiştir. Öğretmen adayları hazırlamış oldukları bu filmleri sınıf ortamında sunduktan sonra filmleri ve senaryoları ile birlikte; filmlerin hangi toplumsal konuda farkındalık yaratmayı hedeflediğini ve filmlerde fen-teknoloji-toplum etkileşiminin nasıl kurulduğunu açıklayan bir Word dosyasını cd içerisinde araştırmacıya teslim etmişlerdir.

\section{Araştırma verilerinin toplanması ve analizi}

Araştırma verileri öğretmen adayları tarafından hazırlanan eğitsel kısa filmler ile araştırmacı tarafindan hazırlanan açık uçlu sorular yardımıyla toplanmıştır.

\section{Eğitsel kısa filmler}

Araştırmada veri toplama aracı olarak kullanılan eğitsel kısa filmlerin nasıl hazırlandığı, içerikleri ve uygulama süreci gibi ayrıntılara yukarıdaki bölümde yer verildiği için tekrar değinilmemiştir. Araştırmada yer alan eğitsel kısa filmler araştırmanın soruları ve amacı doğrultusunda, araştırmacı tarafından hazırlanan dereceli puanlama anahtarı (rubrik) yardımıyla incelenmiştir. Dereceli puanlama anahtarında yer alan sorular araştırmacı tarafından hazırlanmış olup; hazırlanan sorular fen alanında uzman üç araştırmacının görüşüne başvurularak da değerlendirilmiştir. Böylece hazırlanan soruların "görünüş geçerliği”" sağlanmıştır. Yapılan değerlendirme doğrultusunda sorulardan ikisi elenmiş ve 10 sorudan oluşan dereceli puanlama anahtarının son hali oluşturulmuştur. Dereceli puanlama anahtarında yer alan sorular doğrultusunda filmlerde yer alan olumlu/olumsuz durumlar, fen ve toplum ilişkisinin kurulup kurulmadığı, fen kavramlarının doğru bir şekilde verilip verilmediği, filmlerde kullanılan materyaller, ses ve görüntü kalitesi, senaryo ve kurgunun uyumu gibi farklı başlıklar incelenerek değerlendirilmiştir. Dereceli puanlama anahtarının tamamına bulgular bölümünde yer verilmiştir.

Dereceli puanlama anahtarında yer alan soruların değerlendirmesi evet (E), hayır $(\mathrm{H})$ ve kısmen (K) olmak üzere üç farklı kategoride yapılmıştır. Araştırmacı öncelikli olarak her bir filmi izlemiş ardından ayrıntılı bir analize tabi tutmuştur. Bu bağlamda dereceli puanlama anahtarında yer alan her bir soru için filmler tekrar tekrar izlenmiş ve dereceli puanlama anahtarında yer alan kategoriler bu doğrultuda tamamlanmıştır. Araştırmacı tarafindan yapılan değerlendirme sonrasında basit yüzdelik hesaplama yapılarak mevcut veriler yorumlanmıştır. Araştırmada dereceli puanlama anahtarının yanı sıra her bir filmin olumlu-olumsuz yönleri de araştırmacı tarafından ayrı ayrı incelenerek değerlendirilmiş ve tablo haline getirilerek sunulmuştur. 
Açık uçlu sorular

Araştırmanın ikinci veri toplama aracı olan açık uçlu sorular, öğretmen adaylarının eğitsel kısa filmlere ve öğretim sürecinde kullanılmasına ilişkin görüşlerini belirlemeyi hedeflemektedir. Öğretmen adaylarının ilgili görüşlerinin ayrıntılı bir şekilde ortaya konması amacıyla araştırmacı tarafindan 10 farklı soru hazırlanmış, ardından hazırlanan bu sorular araştırmanın hedefi doğrultusunda yeniden incelenerek soru sayısı 7'ye düşürülmüştür. Ayrıca sorular alanda çalışan uzman 3 araştırmacı tarafından daha incelenmiş, böylece soruların "görünüş geçerliği" sağlanmıştır. Son incelemenin ardından soru sayısı 4 olarak belirlenmiştir.

Açık uçlu soruların değerlendirilmesi sürecinde ise içerik analizi yapılmıştır. Buna göre öncelikli olarak sorulara verilen yanıtlar kodlanmış, elde edilen kodlar temalar altında toplanmıştır. Temalar oluşturulduktan sonra her bir temanın tekrarlanma sıklığı (f) belirlenmiş ve basit yüzdelik hesaplama yapılarak tablolar halinde sunulmuştur. Açık uçlu sorulardan elde edilen veriler, geçerlik ve güvenirliğin sağlanması amacıyla konunun uzmanı iki araştırmacı tarafindan daha kodlanmıştır. Farklı araştırmacılar tarafından yapılan değerlendirme sonrasında elde edilen verilerin tutarlılığı ise Patton'un (2002) belirttiği şekilde yapılmıştır. Yapılan analiz sonrasında araştırmacılar arasındaki tutarlılık \%88 olarak belirlenmiştir. Ayrıca araştırmanın geçerlik ve güvenirliğinin arttırılması amacıyla veri toplama süreci, bu süreçte kullanılan ölçme araçları, verilerin nasıl analiz edildiği gibi başlıklar ayrıntılı bir şekilde açıklanmış ve sorulara ilişkin yanıtlar birebir alıntılarla örneklenmiştir.

\section{Bulgular}

Araştırmadan elde edilen bulgular "eğitsel kısa filmlerin incelenmesine ilişkin bulgular" ve "açık uçlu sorulardan elde edilen bulgular olmak üzere iki başlıkta sunulacaktır.

\section{Ĕgitsel kısa filmlerin incelenmesine iliş̧in bulgular}

Araştırmada öğretmen adayları tarafından hazırlanan her bir eğitsel kısa film araştırmacı tarafından hazırlanan bir dereceli puanlama anahtarı ile değerlendirilmiştir. Dereceli puanlama anahtarından elde edilen bulgulara Tablo 2'de yer verilmiştir.

Tablo 2

Eğitsel Kısa Filmlerin İncelenmesine İlişkin Bulgular

\begin{tabular}{|c|c|c|c|}
\hline & $\begin{array}{r}\mathrm{E} \\
(\%)\end{array}$ & $\begin{array}{r}\mathrm{H} \\
(\%)\end{array}$ & $\begin{array}{r}\mathrm{K} \\
(\%) \\
\end{array}$ \\
\hline Filmlerde fen kavramları doğru sunulmuş mu? & 100 & - & - \\
\hline Filmlerde fen-toplum ilişkisi kurulmuş mu? & 60 & - & 40 \\
\hline Filmler işlenen konuya ilişkin farkındalık yaratıyor mu? & 70 & 10 & 20 \\
\hline Filmler eğitsel olma niteliğine sahip mi? & 60 & - & 40 \\
\hline $\begin{array}{l}\text { Filmler eğiticiliğinin yanı sıra, öğrenciyi sıkmadan } \text { konuyu } \\
\text { öğretebilecek nitelikte mi? }\end{array}$ & 10 & 60 & 30 \\
\hline Filmler yaratıcı niteliklere sahip mi? & 30 & 60 & 10 \\
\hline Filmlerdeki senaryo ve kurgu, işlenen konuyu yansitiyor mu? & 40 & 20 & 40 \\
\hline Filmler sınıf seviyesine uygun mu? & 70 & - & 30 \\
\hline Filmlerde uygun materyal kullanılmış mı? & 80 & - & 20 \\
\hline Filmlerin ses/görüntü kalitesi yeterli mi? & 80 & - & 20 \\
\hline
\end{tabular}

Tablo 2'de de görüldüğü gibi öğretmen adaylarının hazırlamış oldukları filmlerin tamamında fen kavramları doğru bir şekilde sunulmuştur. Buna karşın öğretmen adayları hazırlamış oldukları filmlerde fen ve toplum arasındaki ilişkiyi $\% 60$ oranında yeterli bir şekilde kurarken; \%40 oranında kısmen kurabilmişlerdir. Filmlerin \%10'u işlenen konuya yönelik farkındalık oluşturmazken; \%20'si ise kısmen, kalan \%70'lik bölümü ise tamamıla farkındalık oluşturmaktadır. Hazırlanan filmler eğitsel olma niteliğine (E:\%60-K:\%40) sahipken; filmlerin \%60’lık bir diliminin öğrenciye yalnızca konuyu öğretme niteliğinde olduğu görülmektedir. 
Öğretmen adaylarının hazırlamış oldukları filmlerin yalnızca \%10’u öğrenciyi sıkmadan konuyu öğretebilecek nitelikteyken, \%30'unun bu niteliğe kısmen sahip olduğu tespit edilmiştir. Öğretmen adaylarının hazırlamış oldukları filmlerin \%60'1 yaratıcı değilken, \%10'u kısmen bu niteliklere sahiptir. Hazırlanan filmlerin \%20'sinde senaryonun içerikle uyumlu olmadığ 1 görülürken, \%40'ında ise kısmen uyumlu olduğu görülmektedir. Hazırlanan filmlerin genellikle sinıf seviyesine uygun olduğu (\%70), filmlerde uygun materyaller kullanıldığı (\%80) ve ses/görüntü kalitesinin yeterli (\%80) olduğu belirlenmiştir. Elde edilen bu sonucun yanı sira öğretmen adaylarını hazırlamış oldukları filmler olumlu olumsuz yönleri de belirlenmiştir. Elde edilen bulgulara Tablo 3' de yer verilmiştir.

Tablo 3

Eğitsel Kısa Filmlerin Olumlu/Olumsuz Özelliklerine İlişkin Bulgular

\begin{tabular}{|c|c|c|c|}
\hline & Filmin Adı & Olumlu & Olumsuz \\
\hline 1 & $\begin{array}{l}\text { Aynı genden } \\
\text { gelenler }\end{array}$ & $\begin{array}{l}\text {-Sıkıcılıktan uzak olma } \\
\text {-Günlük hayatla ilişkilendirmenin } \\
\text { yapılması } \\
\text {-Bilimsel araştırma sürecinin filme } \\
\text { yansıtılması } \\
\text {-Kısa sürede tüm konunun sunulması }\end{array}$ & $\begin{array}{l}\text {-Anne-çocuk ve abi-kardeş } \\
\text { etkileşimi gibi konularda olums } \\
\text { davranışlar içerme }\end{array}$ \\
\hline 2 & Bitkiler & $\begin{array}{l}\text {-Konu/kavramların açık ve sade bir dille } \\
\text { işlenmesi }\end{array}$ & $\begin{array}{l}\text {-Senaryo ve kurgunun yetersiz } \\
\text { olması } \\
\text {-Filmin dikkat çekiciliğinin az } \\
\text { olması }\end{array}$ \\
\hline 3 & $\begin{array}{l}\text { Bu dünya } \\
\text { bizim }\end{array}$ & $\begin{array}{l}\text {-Günlük hayatla ilişkilendirmenin } \\
\text { yapılması } \\
\text {-Senaryo ve kurgunun konuya olan } \\
\text { dikkati cekmesi }\end{array}$ & $\begin{array}{l}\text {-Filmin dikkat çekiciliğinin az } \\
\text { olması } \\
\text {-İşlenen konuya göre uzun bir } \\
\text { senaryonun yer alması }\end{array}$ \\
\hline
\end{tabular}

-Günlük hayatla ilişkilendirmenin yapılmas1

5

- Günlük hayatla ilişkilendirmenin yapılmas1

6 Bizim evin halleri

$7 \quad$ Yildı planı

-Bilim insanlarının özelliklerine, çalışmalarına ve nasıl çalıştıklarına odaklanma

8 Fatma'nın - Konu/kavramların açık ve sade bir ilaç macerası
-Senaryo ve kurgunun yetersiz olmas1

-İlgili yaş seviyesine uzak bir dil kullanma

-Artarda ilgili fen müfredatındaki kavramlarının gösteriminin yapilmas1

-Senaryo ve kurgunun yetersiz olmas1

-Senaryo ve kurgunun yetersiz olmas1

-Hedeflenen temanın aktarılamamasi -İ̧lenen konuya göre uzun bir senaryonun yer alması

-Filmin dikkat çekiciliğinin az olmas1 
Fen-Toplum Temelli Eğitsel Kısa Filmler Üzerine Bir Çalışma: Fen Bilgisi Öğretmenliği Örneği

9

10
-Konu/kavramların açık ve sade bir dille işlenmesi

-Drama ile konuya ilişkin kavramanın arttırılmas1
-Filmin senaryo-kurgusu ile dramanın iç içe girmiş olması
-Konu/kavramların açık ve sade bir dille işlenmesi
-Kisa olma

-Senaryo ve kurgunun olmamas1

Tablo 3'de de görüldüğü gibi öğretmen adayları tarafindan hazırlanan eğitsel kısa filmlerin olumlu ve olumsuz farklı nitelikleri bulunmaktadır. İncelenen filmlerde genellikle akıcı, sade ve anlaşılır bir dilin olması ile günlük hayatla ilişkilendirmenin yapılması olumlu durumlar olarak nitelenmiştir. Filmlerde yer alan olumsuz durumlar ise genellikle filmin dikkat çekiciliğinin az olması, senaryo/kurgunun yetersiz olması veya olmaması olarak belirlenmiştir.

\section{Açık uçlu sorulara ilişkin bulgular}

Araştırmada öğretmen adaylarının eğitsel kısa filmlere ve öğretim sürecinde kullanılmasına ilişkin görüşlerinin de belirlenmesi amaçlanmıştır. Bu amaçla yöneltilen açık uçlu sorulardan elde edilen sonuçlara tablolar halinde yer verilmiştir. Araştırmanın ilk sorusunda öğretmen adaylarına "eğitsel kısa filmlerin öğretim sürecinde etkili bir şekilde kullanabileceğinizi düşünüyor musunuz? Neden?” sorusu sorulmuştur. Öğretmen adaylarının tamamı soruya "evet" yanıtını vermişlerdir. Sorunun nedenine ilişkin yapmış oldukları açıklamalara Tablo 4'de yer verilmiştir.

Tablo 4

Birinci Soruya İlişkin Bulgular

\begin{tabular}{lcl}
\hline Tema & $\mathrm{f}$ & $\%$ \\
\hline Dikkat çekici olması nedeniyle & 29 & 57 \\
Günlük hayatla iç içe olması nedeniyle & 12 & 24 \\
Eğlendirici olması nedeniyle & 12 & 24 \\
Kalııı olması nedeniyle & 10 & 48 \\
Daha iyi anlamayı sağlaması nedeniyle & 8 & 16 \\
Öğrenmeyi kolaylaştırması nedeniyle & 8 & 16 \\
Farkındalığı arttırması nedeniyle & 4 & 8 \\
Farklı bakış açısı kazandırması nedeniyle & 3 & 6 \\
Görsel zekâya hitap etmesi nedeniyle & 2 & 4 \\
Ön bilgi sağlaması nedeniyle & 2 & 4 \\
\hline
\end{tabular}

Tablo 4'de de görüldüğü gibi öğretmen adayları eğitsel kısa filmleri genellikle "dikkat çekici olması" nedeniyle kullanmayı düşünmektedirler. Bunun yanı sıra öğretmen adaylarının sorunun nedenine ilişkin "günlük hayatla iç içe olma, eğlendirici olma, kalıcı olma, daha iyi anlamayı sağlama ve öğrenmeyi kolaylaştırma" gibi nedenler dolayısıyla da kullanacaklarını belirtmişlerdir. Öğretmen adaylarının soruya ilişkin vermiş oldukları yanıtlar alıntılarda örneklenmektedir.

Araştırmanın ikinci sorusunda öğretmen adaylarına "eğitsel kısa filmleri öğretim sürecinde nasıl (başında-ortasında-sonunda) kullanmayı düşünüyorsunuz? Neden?” sorusu sorulmuştur. Öğretmen adaylarının \%76'sı (f:39) eğitsel kısa filmleri dersin başında kullanmayı düşündüklerini belirtmişlerdir. Buna karşın öğretmen adaylarının \%27'lik (f:14) bir bölümü eğitsel kısa filmleri dersin ortasında; \%14'lük (f:7) bölümü ise dersin sonunda kullanmayı düşünmektedirler. Öğretmen adaylarından ikisi ise (\%4) her aşamada kullanılabileceğini belirtmişlerdir. Öğretmen adaylarının sorunun nedenine ilişkin yapmış oldukları açıklamalara Tablo 5'de yer verilmiştir. 
Tablo 5

İkinci Soruya İlişkin Bulgular

\begin{tabular}{|c|c|c|c|c|c|c|c|c|}
\hline Dersin Başında & $\mathrm{f}$ & $\%$ & Dersin Ortasinda & $\mathrm{f}$ & $\%$ & Dersin Sonunda & $\mathrm{f}$ & $\%$ \\
\hline $\begin{array}{l}\text { Dikkat çekmeyi } \\
\text { sağlaması } \\
\text { nedeniyle }\end{array}$ & 22 & 43 & $\begin{array}{l}\text { Öğrenmeyi test } \\
\text { etmesi nedeniyle }\end{array}$ & 4 & 8 & $\begin{array}{l}\text { Pekiştirmeyi } \\
\text { sağlaması nedeniyle }\end{array}$ & 4 & 8 \\
\hline $\begin{array}{l}\text { Ön bilgi sağlaması } \\
\text { nedeniyle }\end{array}$ & 6 & 12 & $\begin{array}{l}\text { Pekiştirmeyi } \\
\text { sağlaması nedeniyle }\end{array}$ & 3 & 6 & $\begin{array}{l}\text { Anlamayı } \\
\text { kolaylaştırmas1 } \\
\text { nedeniyle }\end{array}$ & 1 & 2 \\
\hline $\begin{array}{l}\text { Günlük hayatı } \\
\text { sorgulamas1 } \\
\text { nedeniyle }\end{array}$ & 3 & 6 & $\begin{array}{l}\text { Ön bilgiyi test } \\
\text { etmesi nedeniyle }\end{array}$ & 1 & 2 & $\begin{array}{l}\text { Kalıc1lığ } \text { arttırmas } \\
\text { nedeniyle }\end{array}$ & 1 & 2 \\
\hline $\begin{array}{l}\text { Güdülemeyi } \\
\text { sağlaması } \\
\text { nedeniyle }\end{array}$ & 2 & 4 & $\begin{array}{l}\text { S1kıcılı̆̆ı önlemesi } \\
\text { nedeniyle }\end{array}$ & 1 & 2 & $\begin{array}{l}\text { Öğrenmeyi test } \\
\text { etmesi nedeniyle }\end{array}$ & 1 & 2 \\
\hline
\end{tabular}

Tablo 5'de de görüldüğü gibi eğitsel kısa filmleri dersin başında kullanacaklarının belirten öğretmen adayları çoğunlukla "dikkat çekmesi" nedeniyle bu şekilde düşündüklerini belirtmişlerdir. Bunun yanı sıra öğretmen adaylarının "ön bilgi sağlaması, günlük hayatı sorgulaması ve güdülemeyi sağlaması" nedenlerini belirttikleri de görülmektedir. Eğitsel kısa filmleri dersin ortasında kullanmayı düşünen öğretmen adayları ise çoğunlukla "öğrenmenin test edilmesi ve pekiştirmenin sağlanması" nedenlerini gerekçe olarak göstermişlerdir. Soruya dersin sonu yanıtını veren öğretmen adayları ise çoğunlukla "pekiştirmeyi sağlaması" nedeniyle bu şekilde düşündüklerini belirtmişlerdir. Öğretmen adaylarının soruya ilişkin vermiş oldukları yanitlar alıntılarda örneklenmektedir.

"Hazırlamış olduğumuz eğitsel kısa filmi dikkat çekmek, ögrencilerin ilgilerini derse vermelerini sağlamak için dersin başında kullanırdım. Bu sayede ilgilerini hem derse çekmiş hem de günlük yaşamda kullandiğı, karşılaştığ birçok olayı kendince sorgulamasını sağlardım. Böylelikle konu daha anlaşılır olurdu ve öğrenciler daha sorgulayıcı birer birey olma yolunda ilerlerdi.” (Ö29)

"Dersin ortasında kullanırdım. Belli bilgilere dikkat etmeleri gerekenleri açılar bunu filmle pekiştirdikten sonra tartışı geri dönütünü alırdım." (Ö19)

"Ben olsam kısa filmi dersin sonunda kullanırım. Başta öğrencilere dersi anlatırım. Daha sonra pekiştirmek amactyla kısa filmi izletirim, üzerinde tartışmalarını sağlarım."(Ö63)

Araştırmanın üçüncü sorusunda öğretmen adaylarına "eğitsel kısa filmlerin öğretim sürecine yönelik katkıları nelerdir?" sorusu sorulmuştur. Soruya ilişkin elde edilen bulgulara Tablo 6' da yer verilmiştir.

Tablo 6

Üçüncü Soruya İlişkin Bulgular

\begin{tabular}{lcc}
\hline Tema & f & $\%$ \\
\hline Öğretim sürecini kolaylaştırma & 8 & 16 \\
İlgi çekmeyi sağlama & 8 & 16 \\
Günlük hayatla ilişki kurmayı sağlama & 6 & 12 \\
Eğlendirerek öğretmeyi sağlama & 4 & 8 \\
Görselleştirmeyi sağlama & 3 & 6 \\
Zamanı iyi kullanmayı sağlama & 2 & 4 \\
\hline
\end{tabular}




\begin{tabular}{lll}
\hline Hayal gücünü geliştirme & 2 & 4 \\
Kalıcı ögrenmeyi sağlama & 2 & 4 \\
Öğretim sürecini güdüleme & 2 & 4 \\
Dersin farklı öğretilebileceğini gösterme & 2 & 4 \\
\hline
\end{tabular}

Tablo 6' da da görüldüğü gibi öğretmen adayları eğitsel kısa filmlerin öğretim sürecine yönelik katkılarını çoğunlukla "öğretim sürecini kolaylaştırma, ilgi çekmeyi sağlama ve günlük hayatla ilişki kurmayı sağlama” olarak açıklamışlardır. Öğretmen adaylarının soruya ilişkin vermiş oldukları yanıtlar alıntılarda örneklenmektedir.

"Görsel olarak sunulduğu için hafizaya uzun süre alınımı sağlar. İlgi çeker, dikkat toplanır, zamanı güzel kullanmayı sağlar. Günlük yaşamla bağlantı kurmayı sağlar. “(Ö27)

“Öğrenciye eğlendirirken de bir şeyler anlatabilmeyi." (Ö58)

Araştırmanın dördüncü sorusunda öğretmen adaylarına "eğitsel kısa filmlerin öğretim sürecine yönelik olumlu/olumsuz etkileri var mıdır? Bu etkilerin neler olduğunu açıklayınız." sorusu sorulmuştur. Soruya ilişkin elde edilen bulgulara Tablo 7'de yer verilmiştir.

Tablo 7

Dördüncü Soruya İlişkin Bulgular

\begin{tabular}{lcclcc}
\hline \multicolumn{1}{c}{ Olumlu (Tema) } & f & $\%$ & \multicolumn{1}{c}{ Olumsuz (Tema) } & f & $\%$ \\
\hline Dikkat çekici olma & 28 & 55 & $\begin{array}{l}\text { Yanlış öğrenmeye neden } \\
\text { olabilme }\end{array}$ & 22 & 43 \\
& & & & \\
Hızlı bilgi aktarımını sağlama & 25 & 49 & Öğretmenin yerini alabilme & 8 & 16 \\
Günlük yaşam ve toplumla iç içe olma & 15 & 29 & Sosyallikten uzaklaştırma & 4 & 8 \\
Hayal gücünü geliştirme & 13 & 25 & Öğrenciyi tembelliğe itme & 4 & 8 \\
Kalıcı olma & 12 & 24 & Öğretmeni tembelliğe itme & 4 & 8 \\
Öğrenmeyi kolaylaştırma & 11 & 22 & Seviyeye uygun olmama & 4 & 8 \\
Öğrenme/öğretme sürecini & 10 & 20 & Eğlence aracı olarak kullanılma & 2 & 4 \\
zenginleştirme & & & & & \\
Farklı zeka tiplerine firsat sunma & 10 & 20 & Bilgilerin soyut kalması & 2 & 4 \\
Eğlenerek öğretme & 9 & 18 & & & \\
Sorgulama becerisi kazandırma & 6 & 12 & & & \\
Ön örgütleyici olma & 5 & 10 & & & \\
Kavramayı arttırma & 5 & 10 & & & \\
Kavramları somutlaştırma & 5 & 10 & & & \\
Öğrenmeyi pekiştirme & 5 & 10 & & & \\
Araştırmaya sevk etme & 3 & 6 & & & \\
Derse katılımı arttırma & 2 & 4 & & & \\
\hline
\end{tabular}

Tablo 7'de de görüldüğü gibi öğretmen adayları çoğunlukla eğitsel kısa filmlerin olumlu etkilerine yönelik açıklamada bulunmuşlardır. Yapmış oldukları açıklamalara göre öğretmen adayları eğitsel kısa filmlerin çoğunlukla "dikkat çekici olması ve hızlı bilgi aktarımını sağlaması" gibi olumlu özelliklerine atıfta bulunmuşlardır. Bunun yanı sıra öğretmen adayları eğitsel kısa filmlerin günlük yaşamla iç içe olması, hayal gücünü geliştirmesi, kalıcı olması, farklı zeka tiplerine firsat sunması, eğlenerek öğretmesi ve sorgulama becerisi kazandırması" gibi olumlu özellikler de belirtmişlerdir. Öğretmen adayları eğitsel kısa filmlerin öğretim sürecinde oluşturabileceği olumsuzluklara yönelikse çoğunlukla "yanlış öğrenmeye neden olabilme" açıklamasında bulunmuşlardır. Ayrıca öğretmen adayları, eğitsel kısa filmlerin öğretmenin yerini alabileceğine yönelik olumsuz bir görüşe de sahip oldukları görülmektedir. Öğretmen adaylarının soruya ilişkin vermiş oldukları yanıtlar alıntılarda örneklenmektedir. 
"Hedef kitlesi geniștir. Ayrıca ögrrencilerin belli bir konuyu daha iyi kavramalarının ve akılda kalıcı olmalarını sağlar. Günlük hayatla ilişki kurmalarında da fayda sağlar. Ayrıca ögretim sürecinde ögrencilerin dikkatini çekmede de önemlidir. Olumsuz yönleri ise; öğretim sürecinde amaç dışı kullanılması olabilir ya da öğrenciler istenmedik bir davranış kazanabilirler. Ayrıca uygun bir yaş düzeyine hitap etmediğinde sılkıtılar yaşanabilir. " (Ö14)

"Olumlu yönler; zamandan tasarruf sağlar, daha iyi ögrenmeyi sağlar, bilginin daha iyi algılanmasının sağlar. Olumsuz yönler ise; ögrrencilerin çalışma isteğini azaltabilir, sosyalleşmelerine engel olabilir, hayal gücünü azaltabilir. "(Ö28)

\section{Tartışma}

Öğretmen adaylarının hazırlamış oldukları eğitsel kısa filmlerin ve öğretim sürecinde kullanılmasına ilişkin görüşlerin incelendiği bu araştırmadan elde edilen sonuçlar, öğretmen adaylarının eğitsel kısa filmlere yönelik görüşlerinin genellikle olumlu olduğunu ve hazırladıkları filmlerin çeşitli eksiklikleri olsa da yeterli niteliklere sahip olduğunu ortaya koymaktadır. Pekdağ ve Marechal (2007a) da filmlerin fen eğitiminde kullanılacak faydalı teknolojik araçlar olduğunu belirtmiş̧; bunun nedenini ise hareketli moleküllerin ve deneysel gösterimlerin sunulması için firsat tanıması ve yeni bilimsel kavramların sunumu ile iletiminde yardımcı olması olarak nitelemişlerdir.

Araştırmada hazırlanan filmlerdeki fen kavramlarının doğru bir şekilde kullanıldığg ve sınıf seviyesine uygun olarak hazırlandığı görülmektedir. Elde edilen bu sonucun öğretmen adaylarının alanları gereği almış oldukları eğitimle ilişkili olduğu düşünülmektedir. Nitekim öğrenciler fizik, kimya, biyoloji gibi pek çok alan bilgisi dersini öğretim sürecinin ilk yıllarında almakta bu bağlamda konuya ilişkin farkındalıkları da yüksek olmaktadır. Elde edilen bu sonucun yanı sıra hazırlanan filmlerde fen ve toplum ilişkisinin içeriğe uygun bir şekilde kurulabildiği görülmektedir. Wagner'ın (1954) belirttiğine göre filmlerin içeriğinde yer alan soruna yönelik etkileyici bir giriş yapmak; izleyicinin konuya oryante olabilmesi açısından önemlidir. Bu bağlamda öğretmen adaylarının hazırlamış oldukları eğitsel kısa filmlerin, öğrencilerin derse yönelik ilgililerini sağlamada etkili birer araç olabileceği de düşünülmektedir. Ayrıca öğretmen adaylarının filmlerin içeriğinde fen ve toplum ilişkisini yeterli bir şekilde kurabilmiş olmalarının, öğretmen adaylarının almış oldukları ders gereği fen ve toplum arasındaki ilişkiyi kurmaları ve günlük hayatla olan bağlantısını açıklamaları ile ilişkili olabileceği düşünülmektedir. Birkök (2008) de filmlerin etkin bir eğitim ve toplumsallaştırma aracı olduğunu belirtmektedir. $\mathrm{Bu}$ bağlamda filmlerin fen ve toplum arasındaki ilişkinin kurulabilmesi adına oldukça etkin bir işlevinin olduğu düşünülmektedir.

Araştırmadan elde edilen bu sonuçların yanı sıra filmlerin akıcı, sade ve anlaşılır bir dile sahip olması ile günlük hayatla ilişkilendirmenin kurulması, filmlerin sınıf seviyesine uygun olması, filmlerde uygun materyallerin kullanılması, ses/görüntü kalitesinin yeterli olması ve filmlerin büyük bir bölümünün (\%90) işlenen konuya yönelik farkındalık oluşturması gibi durumlar filmlerde yer alan olumlu durumlar olarak nitelenmiştir. Wagner (1954) da filmlerde yer alan ses, müzik, görüntü ve özel efektler gibi başlıkların ana temayı aktarabilmek adına özenle seçilmesi gerektiğini, filmlerde yer alan kelime haznesinin ve filmin yapısının izleyici kitlesine göre düzenlenmesi gerektiğini belirtmiş̧tir. Araştırmada öğretmen adayları tarafından hazırlanan filmlerde ilgili pek çok niteliğe yer verilmiş olması nedeniyle filmlerin yeterli olduğu düşünülmektedir.

Araştırmadan elde edilen bu sonuçların yanı sıra öğretmen adaylarının hazırlamış oldukları filmlerde dikkat çekiciliğin az olması, senaryo/kurgunun yetersiz olması veya olmamasi filmlerde yer alan olumsuz durumlar olarak nitelenmiştir. Oysaki Slesinger (1940) eğitsel nitelikteki filmlerin izleyici bilgiyi öğrenmeye heveslendirmesi ve merak uyandırması gerektiğini belirtmiştir. $\mathrm{Bu}$ bağlamda hazırlanan filmlerin bu açıdan eksik kaldığ düşünülmektedir. Araştırmadan elde edilen bu sonuçların yanı sıra hazırlanan filmlerin yarıdan az bir kısmının (\%40) öğrenciyi sıkmadan konuyu öğretme niteliğinde olduğu; benzer bir 
şekilde hazırlanan filmlerin yarıdan az bir bölümünün (\%40) yaratıcı öğelere sahip olduğu belirlenmiştir. Oysaki Wagner (1962) filmlerin hem yaratıcı hem de bilimsel öğelere sahip olması gerektiğine yönelik vurguda bulunmaktadır. Araştırmada öğretmen adaylarının yaratıcı öğelere yeterince yer vermemiş olmasının; araştırmanın yürütüldügü ders sürecinde yaratıcılık üzerine yeterli vurgu yapılmamış olması ile film hazırlama sürecinde fen ve toplum temeline odaklanılmış olmasından kaynaklanabileceği düşünülmektedir.

Öğretmen adayları eğitsel kısa filmleri dikkat çekici olması, günlük hayatla iç içe olması, eğlendirici olması, kalıcı olması, daha iyi anlamayı sağlaması ve öğrenmeyi kolaylaştırması gibi nedenler dolayısıyla meslekleri süresince etkili bir şekilde kullanabileceklerini belirtmişlerdir. Öztaş (2008) da yapmış olduğu araştırmada tarih öğretiminde film kullanımının öğrencilerin düşünme becerilerini ve başarılarını geliştirdiğini, tarih dersine karşı ilgi ve motivasyonlarını arttırdığını ve araştırmaya sevk ettiğini tespit etmiştir. Benzeri bir şekilde Selanik Ay (2010) çalışmasında filmlerin çevre sorunlarına ilişkin bilgi kazandırdığını ve çevre bilinci oluşturduğunu, eğlenceli olduğunu, araştırma yeteneğini geliştirdiğini tespit etmiştir. Tüzel (2013) ise çalışmasında film kullanılarak yürütülen Türkçe derslerinin daha eğlenceli olduğunu ve öğrencilerin kendi yaşamları ile ilişki kurduklarını belirtmişlerdir. Araştırmalardan elde edilen farklı sonuçlar filmlerin öğretim sürecinde etkili bir şekilde kullanılabileceğine ilişkin görüşlere paralellik göstermekle birlikte; filmlerin öğretim sürecine yönelik katkılarını da ortaya koymaktadır.

Araştırmadan elde edilen sonuçlara göre öğretmen adayları eğitsel kısa filmleri dikkat çekmesi, ön bilgi sunması, günlük hayatı sorgulaması ve güdülemeyi sağlaması gibi nedenler dolayısıyla çoğunlukla dersin başında kullanmayı düşündüklerini belirtmişlerdir. Michel, Roebers ve Schneider (2007) eğitsel filmlerin dersin başında kullanılabileceğini, bu bağlamda filmlerin kullanım amacını karmaşık konulara geçmeden önce "ön örgütleyici” olması olarak nitelemişlerdir. Elde edilen bu sonucun yanı sıra araştırmada eğitsel filmleri öğrenmenin test edilmesi ve pekiştirmenin sağlanması gibi nedenlerle dersin ortasında kullanmayı düşünen öğretmen adaylarının olduğu da görülmektedir. Birkök (2008) de filmler aracılığıyla karmaşık bilgilerin imajlaştıılddı̆ını ve kavramların metinlere göre daha kolay anlaşılmasının sağlandığını belirtmektedir.

Öğretmen adayları eğitsel kısa filmlerin öğretim sürecine yönelik olumlu katkıları olduğunu düşünmektedirler. Akbaş'ın (2015) yapmış olduğu çalışmada da eğitsel kısa filmler, izleyen öğrenciler tarafindan faydalı bulunmuştur. Bu araştırmadan elde edilen sonuçlarda ise öğretmen adayları eğitsel kısa filmlerin çoğunlukla öğretim sürecini kolaylaştırma, ilgi çekmeyi sağlama ve günlük hayatla ilişki kurmayı sağlama, hayal gücünü geliştirme, kalıcılığı sağlama, farklı zeka tiplerine firsatlar sunma, eğlenerek öğretmeyi sağlama ve sorgulama becerisi kazandırma gibi olumlu katkılarından söz etmişlerdir. Vandewater ve Bickham'ın (2004) çalışmasında ise eğitsel medya kullanımının çocukların okuma becerilerine ve aile içinde yaşanan strese yönelik olumlu etkisinin olduğu tespit edilmiştir.

Araştırmadan elde edilen bu sonuçlara karşın öğretmen adayları eğitsel kısa filmlerin öğretim sürecinde oluşturabileceği olumsuzluklara yönelik açıklamada bulundukları da görülmektedir. Buna göre öğretmen adaylarının çoğunlukla yanlış öğrenmeye neden olabilme ve öğretmenin yerini alabilme gibi olumsuzluklara atıfta bulundukları belirlenmiştir. Wagner (1954) da sınıf ortamında izlenilen filmlerin, öğretim süreci göz önüne alınarak planlanması gerektiğini; bu bağlamda 5 ile 30 dakika arasında olması gerektiğini belirtmiştir. Ayrıca Wagner'ın (1962) farklı bir çalışmasında belirttiğine göre filmlerin izlenmesi sürecinde öğrenciler daha açık uçlu ve çelişkili durumları düşünmeye sevk edilmeli, böylece öğrencilerin filmlere yönelik anlamlandırma ve düşünme süreci de desteklenmelidir.

\section{Sonuç ve Öneriler}

Araştırmadan elde edilen sonuçlar eğitsel kısa filmlerin öğretim sürecinde kullanılmasına ilişkin görüşleri ortaya koymakla birlikte; bu süreçte yaşanabilecek sıkıntıları da ortaya koymaktadır. Eğitim-öğretim süreci farklı pek çok değişkenle şekillenebilen ve farklı pek çok değişkenden etkilenebilen bir süreçtir. Barkan ve Eroğlu (2004) geleneksel eğitim modellerindeki en önemli 
kaygının etkili ve verimli bilgiyi üretebilmek, çağdas eğitim modellerindekinin ise etkili ve verimli bilgi dolaşım ve paylaşım kanallarını geliştirebilmek olduğunu ifade etmiştir. Nitekim eğitsel kısa filmlerin de bilginin etkili bir şekilde iletilmesi ve paylaşılması adına kullanılabilecek, çağdaş eğitim modeliyle uyumlu bir öğretim aracı olduğu düşünülmektedir. Birkök'ün (2008) belirttiğine göre ise filmler fen ve sosyal bilimler alanındaki hemen hemen tüm branşlarda herhangi bir olgunun öğretilmesi için kullanılabilmektedir. Buna karşın Wagner (1962) filmlerin öğretim sürecinde kullanılabilmesi için işlenen konuyu etkili ve doğrudan öğretebilecek nitelikte öğretim tekniklerinin uygulanmas1 gerektiğini belirtmiş ve bu süreci iyi yönetebilecek bir öğretmenin filmlerden öğretim konusunda oldukça başarılı olabileceğini ifade etmiştir.

Öğretim sürecinin şekillendirilmesi ve yürütülmesinde en önemli etken öğretmenlerdir. $\mathrm{Bu}$ bağlamda öğretmenlerin günümüz şartlarındaki gelişmeleri izleyerek uygun öğretim araçlarını derslerine entegre etmeleri, öğrencilere farklı bilgi ve becerileri çeşitli yöntemtekniklerle aktarabilmeleri gerektiği düşünülmektedir. Koç (2011) öğretim sürecinin yürütülebilmesi için teorik bilginin pedagojik prensiplerle bir arada nasıl uygulanacağının bilinmesi gerektiğini belirtmektedir. Bu durum öğretmenlik mesleğini yürütmekte olan ve gelecekte bu mesleği yürütecek olan öğretmen adaylarına önemli sorumluluklar da yüklemektedir. Nitekim araştırmadan elde edilen sonuçlar öğretmen adaylarının öğretim sürecinin yürütülmesi ve bu süreçte farklı öğretim yöntem-teknikleriyle desteklenmesi konusundaki farkındalıklarının yüksek olduğunu göstermekle birlikte; yeni ve farklı öğretim yöntem-tekniklerini kullanma ve bunları derslerine entegre etme konusunda da istekli olduklarını ortaya koyar niteliktedir. Araştırmadan elde edilen sonuçlar geleceğin öğretmenleri olan öğretmen adaylarına henüz fakültede iken farklı bilgi ve becerilerin sunulması, bunların nasıl uygulanabileceği konusunda bilgilendirmede bulunulmasının önemini de gösterir niteliktedir. Bu bağlamda gelecekte çalışacak olan araştırmacılara belirli bir konuda hazırlanan eğitsel kısa filmlerin öğretmen adaylarının gerek öğretim gerekse farklı becerilerine yönelik etkisinin tespit edilmesi; ayrıca hazırlanan filmlerin ilgili sınıf seviyesinde uygulanarak öğretim sürecine yönelik etkililiğinin belirlenmesi önerilmektedir.

\section{Kaynaklar}

Akbaş, O. (2011). Bir öğrenme nesnesi olarak eğitsel kısa filmler: Öğretmen adaylarının çektikleri eğitsel kısa filmler üzerine bir değerlendirme. Gazi Üniversitesi Endüstriyel Sanatlar Ĕ̈itim Fakültesi Dergisi, 27, 15-27.

Akbaş, O., Canoğlu, S. N. ve Ceylan, M. (2015). Eğitsel kısa film ve videoları yeniden düşünmek: Eğitsel kısa film ve video yarışmasına ilişkin bir değerlendirme. Kuramsal Ĕ̈itim Bilim Dergisi, 8(2), 282-296. DOI: http://dx.doi.org/10.5578/keg.9160

Attia, A. K., Rahman, D. A. M. A. ve Kamel, L. I. (1997). Effect of an educational film on the health belief model and breast self-examination practice. Eastern Mediterranean Health Journal, 3(3), 435-443.

Barkan, M. ve Eroğlu, E. (2004). Eğitim iletişiminde çağdaş ortamlar: “.. iletişim bir sorun kaynağı mı yoksa çözüm seçeneği mi?” The Turkish Online Journal of Educational Technology - TOJET, 3(3), 115-123.

Barnett, M., Wagner, H., Gatling, A., Anderson, J., Houle, M. ve Kafka, A. (2006). The impact of science fiction film on student understanding of science. Journal of Science Education and Technology. 15(2), 179-191. DOI: 10.1007/s10956-006-9001-y

Birkök, M. C. (2008). Bir toplumsallaştırma aracı olarak eğitimde alternatif medya kullanımı: Sinema filmleri. Uluslararast Insan Bilimleri Dergisi, 5(2), 1-12. DOI: 10.14687/ijhs.v5i2.574

Bruner, J. (2008). Ĕ̈itim Süreci. T. Öztürk (Çev.) Ankara: Pegem Akademi.

Cuban, L. (1986). Teachers and machines: the classroom use of technology since 1920. New York: Teachers College Pres.

Demircioğlu, İ. H. (2007). Tarih öğretiminde filmlerin yeri ve önemi. Bilig, 42, 77-93 
Depover, C., Giardina, M. ve Marton, P. (1998). Les environnements d'apprentissage multimédia. Paris: L'Harmattan.

Goll, J. G. ve Woods, B. J. (1999). Teaching chemistry using the movie Apollo 13. Chemistry Everyday for Everyone. 76(4), 506-508.

İnce Yakar, H. G. (2013). Sinema filmlerinin eğitim amaçlı kullanımı: tarihsel bir değerlendirme. Hasan Ali Yücel Eğitim Fakültesi Dergisi, 19(1), 21-36.

Koc, M. (2011). Let's make a movie: Investigating pre-service teachers' reflections on using video-recorded role playing cases in Turkey. Teaching and Teacher Education, 27(1), 95-106.

McClusky, F. D. (1947). The Nature of the educational Film. Hollywood Quarterly. 2(4), 371380. Erişim adresi: http://www.jstor.org/stable/1209533

Michel, M., Roebers, C. M. ve Schneider, W. (2007). Educational films in the classroom: Increasing the benefit. Learning and Instruction, 17, 172-183.

Okumuş, S. (2014). Yeni medya ve kısa film olgusu. (Yayımlanmamış yüksek lisans tezi). İstanbul Kültür Üniversitesi Sosyal Bilimler Enstitüsü, İstanbul.

Öztaş S. (2008). Tarih öğretimi ve filmler. Kastamonu Ĕ̆itim Dergisi, 16(2), 543-556.

Patton, M. Q. (2002). Qualitative research \& evaulation methods. London: Sage Publication.

Pekdağ, B. ve Le Marechal, J. (2007a). Bilimsel Filmlerin Hazırlanması. Necatibey Eğitim Fakültesi Elektronik Fen ve Matematik Ĕ̈itimi Dergisi (EFMED), 1(1), 57-84.

Pekdağ , B. ve Le Marechal, J. (2007b). Memorisation of information from scientific movies, R. Pintó ve D. Couso (Yay. haz.). Contributions from Science Education Research içinde (s.199-210). Springer.

Pekdağ, B. ve Le Marechal, J. (2010). Movies in chemistry education. Asia-Pacific Forum on Science Learning and Teaching, 1(1), Article 15.

Selanik Ay, T. (2010). Sosyal bilgiler dersinde çevre bilinci kazandırmada medya ürünlerinden yararlanmaya ilişkin öğrenci görüsşleri. Uluslararası Avrasya Sosyal Bilimler Dergisi, l(1), 76-93.

Slesinger, D. (1940). The film and education. The Journal of Educational Sociology, 13(5), $263-$ 267.

Stoddard, J. D. (2009) The ideological implications of using "educational" film to teach controversial events. Curriculum Inquiry, 39(3), 407-433, DOI: 10.1111/j.1467873X.2009.00450.X

Tüzel, S. (2013). Okul ile öğrenci yaşamı arasındaki duvarları yıkmak: popüler medyayı sınıfa taşımak. I. Türkiye Çocuk ve Medya Kongresi Bildiriler Kitabı, 1, 13-41.

Wagner, R. W. (1954). Design in the Educational Film. Educational Research Bulletin, 33(6), 141-148.

Wagner, R. W. (1962). The creative educational film. Educational Technology Research and Development, 10(4), 275-283.

Vandewater, E. A. ve Bickham, D. S. (2004). The impact of educational television on young children's reading in the context of family stress. Journal of Applied Developmental Psychology, 25(6), 717-728.

\section{Extended Abstract}

\section{Introduction}

Developments in today's technology have also resulted in the differentiation of the ways for reaching the knowledge. Many factors especially such as easy access to the internet and the use of different means of communication in this process have also brought along the change in the process of attaining knowledge. Individuals usually prefer easily accessible sources like visual and written media in attaining knowledge. With the help of these means, it is possible to access different concepts and subjects both within visual presentation and in a comprehensible language, and in this way the comprehension of complexed concepts and subjects also get easier. This condition constitutes the focus of the study and accordingly the study has included 
educational films prepared by the teacher candidates. In the study, the teacher candidates have been expected to take the scientific concepts/subjects as their starting point in accordance with the department that they study in and to prepare an educational film within the context of a problem through which they can bring science and society together. It is thought that the results to be obtained from the study will not only put forth the ideas regarding the use of films in education process but also reflect upon how the teacher candidates handle and interpret the problems within science and society according to different points of views. In this respect, the aim of the study is to analyse the educational short films prepared by teacher candidates and to assess the opinions regarding their use in the education process.

\section{Method}

The study is in the survey method and has been conducted with 51 teacher candidates studying their $2^{\text {nd }}$ year at a state university in Istanbul during 2014-1015 spring term. The study has been conducted within the "Sciences and Society" course which was given as a selective course by the researcher. The teacher candidates participating in the study have been selected from the group taking this course with the method of random sampling. The study included 10 different educational short films within the guidance of the researcher.

Before the preparation of the educational short films, the researcher provided the teacher candidates with general information on the visual and written means of media and the use of these means in education. Afterwards, the teacher candidates were given information about the preparation process of educational short films and educational short film examples from different media sources were analyzed. The teacher candidates were asked to design their films taking a science subject within the primary school curriculum as their starting point while preparing the educational short films and to include a social problem in this process. Each short film was limited to 15 minutes and the films were presented within the class on pre-determined dates.

Educational short films as one of the data collecting means for the study were assessed within the questions and the aim of the study with the help of a graded scoring rubric consisting of three categories (yes, no and partially) and prepared by the researcher. The questions in the graded scoring rubric were prepared by the researcher and the questions were assessed by taking the opinions of three researchers who are expert in science. After the examination of the films, each title in the graded scoring rubric was studied and available data were interpreted with a simple percentage calculation.

Open-ended questions which are the second data collecting means target to determine the opinions of teacher candidates on educational short films and their use in education process. In order to present the opinions of the teacher candidates, different questions were prepared by the researcher, these questions were examined by 3 experts in the field, and the number of questions was determined to be 4 . The open-ended questions were assessed with content analysis. In this regard, primarily the answers given to the questions were coded and the codes obtained were gathered under themes. After the formation of the themes, the repetition frequency ( $f$ ) of each theme was determined and presented in table after a simple percentage calculation. The data obtained from open-ended questions were coded again by 2 more experts with the purpose of attaining validity and reliability. After the evaluation by different researchers, the consistency of the obtained data was determined as $88 \%$.

\section{Results and Discussion}

It has been seen in the study that scientific concepts were used correctly in all of the films prepared by the teacher candidates. It is thought that this result is related to the education that teacher candidates acquired as part of their department. It is also seen that science-society relation could be established in the films. It is thought that this situation is related to the fact that teacher candidates questioned the relation between science and society and explained its connection with daily life benefitting from the course that they took.It has been reported that almost all of the films raised awareness about the subject and involved educational qualities. 
Along with these results it has also been determined that the films were mostly suitable for the grade level, appropriate materials were used in the films and the quality of sound and video was adequate. When the films were evaluated in terms of positive and negative qualities, the fact that the films generally had a flowing, simple and comprehensible language and that they had daily life associations were regarded as positive aspects. On the other hand, the negative aspects of the films were determined to be lack of attention grabbing and inadequacy or absence of scenario.

Teacher candidates generally explained the contributions of educational short films as "facilitation of the educational process, grabbing attention, establishing relations with the daily life, enabling fast information transfer, enlarging imagination, being permanent, offering opportunities for different types of intelligence, teaching in an enjoyable way and enabling the questioning skill". Along with this conclusion the teacher candidates also think that educational short films might have negative aspects such as "causing wrong learning and substituting the learning". It was also determined that $76 \%$ of teacher candidates think of using the educational short films in the beginning of the class, $27 \%$ of them in the middle of the class, $14 \%$ at the end of the class and $4 \%$ think of using them in all stages of the class.

Education process can be shaped by many different factors and variables. The most important factor in shaping and conducting the education process is the teacher. In this regard, it is thought that teachers need to follow the recent developments and integrate the suitable education means into their course and to transfer different knowledge and skills to the student by using various methods and techniques. Accordingly, the results obtained from the study not only show that the awareness of the teacher candidates about conducting the educational process and supporting the process with different teaching methods was high but also the teacher candidates showed willingness in using different teaching methods and integrating these into their lessons. The study results demonstrate the significance of presenting different knowledge and skills to the teacher candidates while they are at the faculty yet and providing information as to their implementation. The future researchers to study in this field are recommended to determine the effect of educational short films prepared about a specific subject on the teaching and other skills of teacher candidates and also to implement the films in the relevant grade level and to determine their efficiency in education process. 